\title{
"Farming with Alternative Pollinators" approach increases pollinator abundance and diversity in faba bean fields
}

\author{
Ahlam Sentil ${ }^{1,2}$ (D) Patrick Lhomme ${ }^{1,2} \cdot$ Denis Michez $^{1} \cdot$ Sara Reverté $^{1} \cdot$ Pierre Rasmont $^{1} \cdot$ Stefanie Christmann $^{2}$
}

Received: 20 January 2021 / Accepted: 21 September 2021 / Published online: 30 October 2021

(c) The Author(s) 2021

\begin{abstract}
Pollinators are threatened worldwide and strategies and measures to support their conservation are proliferating. Among them, the approach "Farming with Alternative Pollinators" (FAP) aims to support pollinators by seeding strips of pollinatorattracting cultivated plants surrounding the crops, and simultaneously providing income to the farmer. In this study we assessed whether this approach supports pollinator diversity in agro-ecosystems and increases flower visitor diversity and abundance in faba bean fields in north-west Morocco. We tested the impact of FAP using a variety of marketable habitat enhancement plants (MHEP): flax, coriander, arugula, chia and canola. A total of 62 pollinator species were recorded, among which almost half of them are new records for the region. Most wild pollinators recorded in faba bean were digger bees (genus Anthophora) and long-horn bees (genus Eucera). MHEP shared diverse flower visitors with faba bean and hosted diverse pollinator groups that did not meet their food requirements from the main crop. The FAP approach highly increased flower visitor abundance and diversity in the whole FAP fields, however it did not generate significant pollinator spillover towards the main crop. Implications for insect conservation: our results show that the FAP approach is an effective approach to mitigate pollinator decline in agro-ecosystems.
\end{abstract}

Keywords Pollinators $\cdot$ Faba bean $\cdot$ Canola $\cdot$ Coriander $\cdot$ Anthophora $\cdot$ Eucera

\section{Introduction}

The huge contribution of pollinators to ecosystem services and agricultural production is being increasingly recognized (Klein et al. 2007; Potts et al. 2016; Christmann 2019a). Worldwide pollinators ensure the sexual reproduction of $87 \%$ of all the flowering plants (Ollerton et al. 2011) and the production of more than $75 \%$ of the leading food crops (Klein et al. 2007). Unfortunately, pollinators have significantly declined over the last two decades (Biesmeijer et al. 2006; Potts et al. 2010; Goulson et al. 2015; IPBES 2016; Gill et al. 2016; Goulson 2019). As a result, pollination services may become less available for wild or domesticated

Ahlam Sentil

ahlam.sentil@student.umons.ac.be

1 Laboratory of Zoology, Research Institute for Biosciences, University of MONS, Place du Parc 20, 7000 Mons, Belgium

2 International Center of Agricultural Research in the Dry Areas, Station Exp. INRA-Quich, rue Hafiane Cherkaoui, BP 6299, 10112 Rabat, Morocco plants and more costly due to higher rental fees for honey bees (Ferrier et al. 2018; Reilly et al. 2020). The main drivers of pollinator loss are land-use changes, agricultural intensification, pesticide use, plant extinction and invasive species (Potts et al. 2010; Gill et al. 2016; Mogren et al. 2016; Vanbergen et al. 2018; Gill et al. 2016; Sánchez-Bayo and Wyckhuys 2019).

Nearly $40 \%$ of the land on Earth has been converted to agricultural land and roughly half of the remaining land is desert (Foley et al. 2005). Agricultural practices are negatively impacting the natural habitats and floral resources required to sustain pollinators (Aizen and Harder 2009; Gill et al. 2016; Aizen et al. 2019). First, homogenous landscapes can threaten specialist pollinators (i.e. pollinators with narrow floral choices) if they are not able to forage on the pollinator dependent crops. Moreover, the flowering period of pollinator dependent crops can be shorter (i.e. a few weeks) than the time needed for the pollinator to accomplish its full cycle of development. Outside this crop blooming period, pollinators would require additional floral resources. Last, pollinator independent crops like wheat and barley do not provide nectar or pollen 


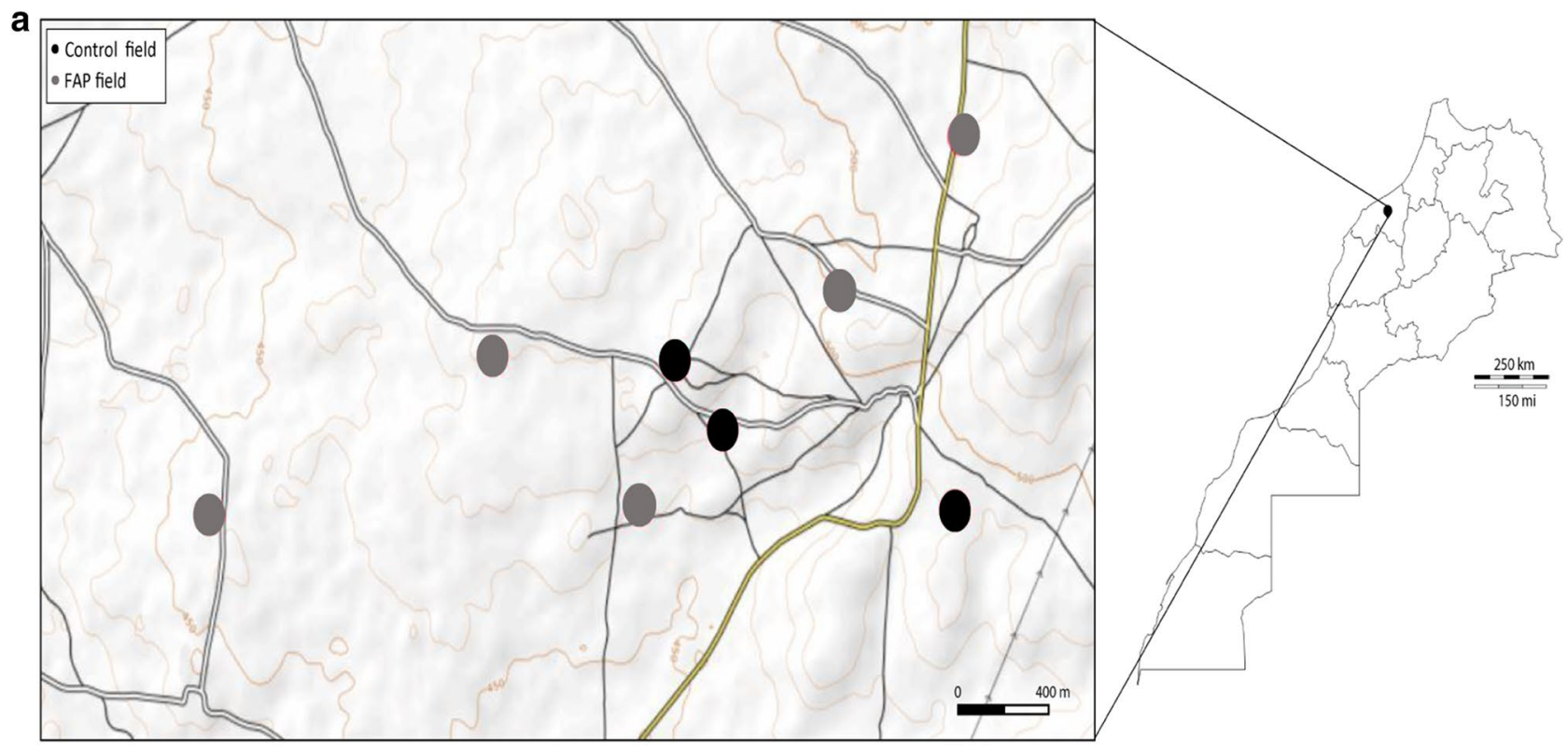

b

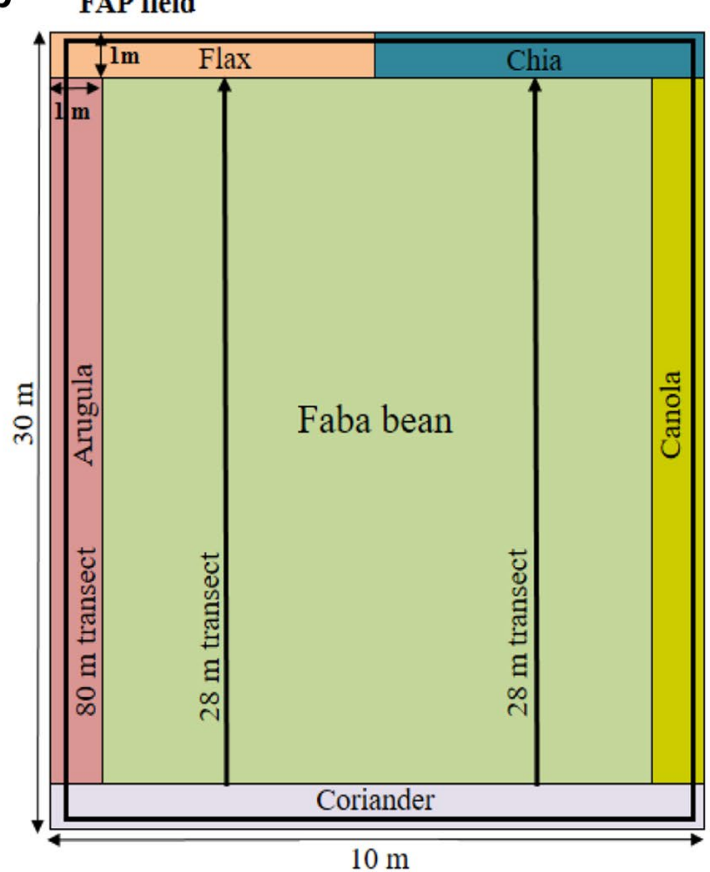

c

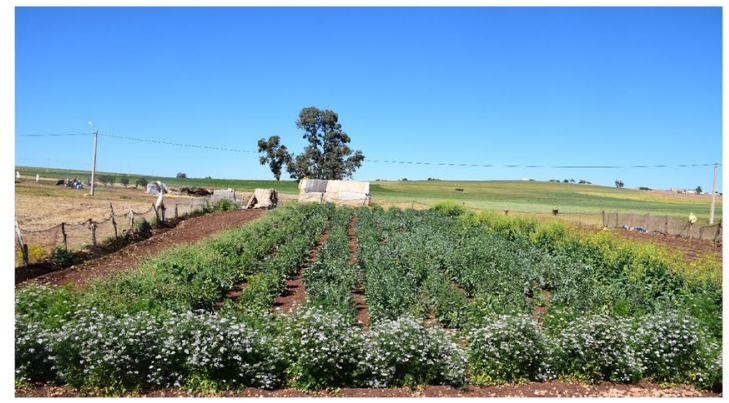

Control field

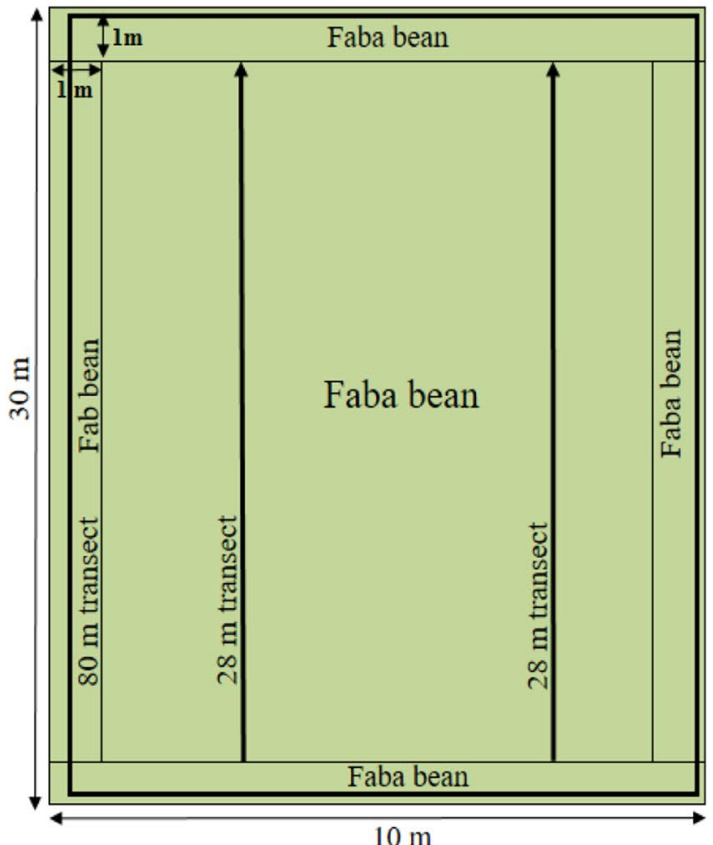

d

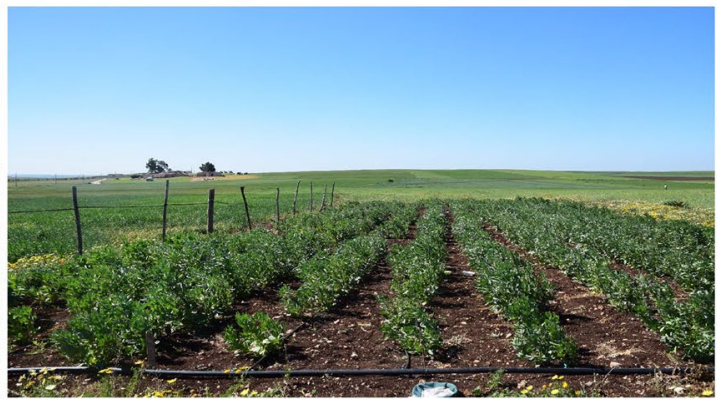


4Fig. 1 a Map of Morocco on the right side and map of the study region with the locations of the eight sites (five FAP fields and three control fields) on the left side. b Experimental designs of FAP and control fields. In the left, FAP field (faba bean in $75 \%$ of the field surrounded by Marketable Habitat Enhancement Plants). In the right, control field (faba bean only), the three arrows correspond to the three transects. $\mathbf{c}$ Photo of FAP field of faba bean surrounded by marketable habitat enhancement plants in full bloom; coriander in the bottom, canola on the right side, arugula on the left, chia and flax on the top (Ouled Sghir, Settat). d Photo of control field of faba bean in full bloom (Ouled Sghir, Settat)

for pollinators. In Morocco, cereals cover $54 \%$ of arable lands (Ministry of Agriculture, Fisheries, Rural development, Water and Forests 2019). The increase of the relative importance of pollinator independent crops and the agricultural intensification (e.g. development of monoculture) adopted by farmers may therefore lead to a huge loss of ecosystem services provided by these insect pollinators. This loss can have strong negative cascading effects on the pollination services provided to wild plants and the remaining pollinator-dependent crops (Lever et al. 2014; Christmann 2019a).

Within the EU, Agri-Environment Schemes (AES) provide financial support to farmers in order to adopt agricultural practices to boost pollinator diversity and abundance. The budget allocated to implement this approach from 2007 to 2013 was up to $€ 22.2$ billion (McCracken et al. 2015; EU 2020). This approach, although important, is not scalable to low and middle-income countries such as Morocco due to the high costs of farmer subsidization (Christmann et al. 2017). To achieve pragmatic solutions, farmers need to be involved in pollinator protection. They can contribute to the mitigation of the environmental impact of managed landscapes through the seeding of pollinator dependent crops that offer pollen and nectar resources and provide simultaneous income.

"Farming with Alternative Pollinators" (FAP) (Christmann and Aw-Hassan 2012; Christmann et al. 2017, 2021; Christmann 2019b) is a new approach aiming to increase farm income as an incentive for farmers to engage in pollinator protection. Alternative pollinators refer to wild pollinators that farmers currently do not value for their wide contribution in agricultural production (Christmann et al. 2017). Farmers dedicate $25 \%$ of their fields to seed marketable habitat enhancement plants (MHEP) that provide pollen and nectar for pollinators. The MHEP potentially offer nutrition and shelter to many flower visitors and can complement the food requirement for generalist bees that do not meet this requirement with the main crop. Additionally, as Kleijn et al. (2015) confirmed for wild flower strips, MHEP can also host specialist species that are not able to forage on the main crop. Therefore, MHEP from FAP approach can contribute to supporting pollinator diversity, pollination service and produce marketable products for sale (Christmann et al. 2017, 2021).

In order to assess the impact of the FAP approach on pollinator diversity and abundance on species level, a study on faba bean was carried out in 2019 in the Settat region in north-west Morocco. Faba bean is one of the staple crops in Morocco and represents $48 \%$ of grain-legume area. Production of this legume in Morocco in 2017 was around 280,000 tons (Matieres 2019). In Settat, faba bean represents $15 \%$ of grain-legume area (SPMOCA Settat 2019). Faba bean is a pollinator dependent crop (Klein et al. 2007; Bishop and Nakagawa in press). It is self-fertile with about equal amount of self and cross-pollination occurring depending on the insect pollinators (Palmer et al. 2009). Pollination of faba bean in Europe is mainly provided by honey bees (Apis mellifera), bumble bees (genus Bombus) and digger bees (genus Anthophora) (Bond and Kirby 1999; Pierre et al. 1999; Carré et al. 2009; Marzinzig et al. 2018). The pollination of faba bean in Morocco is not yet documented.

This study aims to (1) identify the main visitors of faba bean in Settat, (2) test if the FAP approach increases species richness and abundance of flower visitors in faba bean fields compared to monocultural control sites and (3) assess if the flower visitors collected in faba bean are also visiting the MHEP and vice versa. Based on previous studies, our hypotheses are that (1) the main faba bean visitors are long tongued bees; (2) FAP increases the insect species diversity and abundance as floral and flower visitor diversities are correlated; (3) MHEP and main crop share common floral visitors.

\section{Materials and methods}

\section{Study area}

The study was conducted in Ouled Sghir, a semi-arid rural municipality in the north-west of Morocco, it is $20 \mathrm{~km}$ distant from Settat city of the Chaouia-Ouardigha region. The landscape is characterized by relatively homogeneous land dominated by intensively cultivated land (90\%), followed by forest fragments and urban areas. Cereal production occupies almost $90 \%$ of the arable land while pollinator dependent crops such as faba bean, alfalfa, flax and clover do not exceed $4 \%$ of the arable land (SPMOCA Settat 2019).

\section{Study field trials}

The main crop selected was faba bean (Vicia faba, Fabaceae) and the MHEP were: chia (Salvia hispanica, Lamiaceae), canola (Brassica napus, Brassicaceae), flax (Linum usitatissimum, Linaceae), arugula (Eruca sativa, Brassicaceae) and coriander (Coriandrum sativum, Apiaceae). The selection 
of MHEP was made together with participating farmers and was based on their attractiveness to pollinators (Vastola 2015; Holzschuh et al. 2016; Thom et al. 2018; Shakeel et al. 2019; Sharma and Meena 2019) and their period of bloom that should partly overlap with that of faba bean. Since flower color and morphology play an important role in the attraction of flower visitors (Wester and Lunau 2017), the selected MHEP had various flower shape, size, tube length and color (Online Resource 1). Eight fields of $300 \mathrm{~m}^{2}$ $(30 \times 10 \mathrm{~m})$ were selected ( 5 FAP fields and 3 control fields) (Fig. 1a). In FAP fields, the main crop (faba bean) occupied $75 \%$ of the field area with the same planting scheme and cultivars and the MHEP were planted in the margins of the main crop (25\% zone) (Fig. 1b, c). The control fields had faba bean as monoculture in $100 \%$ of the field (Fig. 1b, d). Strips of flax and chia were $4 \mathrm{~m}$ long and $1 \mathrm{~m}$ wide each, the strip of coriander was $8 \mathrm{~m}$ long and $1 \mathrm{~m}$ wide and strips of canola and arugula were $30 \mathrm{~m}$ long and $1 \mathrm{~m}$ wide each (Fig. 1b). The fields were managed with similar farming practices (i.e. dung, pesticide and water treatments). A herbicide containing the active ingredient glyphosate was applied at low dose on faba bean every 15 days from the early flowering stage to control broomrapes. The MHEP and faba bean were sown in 2018 in early (5-6th) and late November (29-30th), respectively. Bee hives were absent from the farmers' land.

The sites were distant of minimum $600 \mathrm{~m}$, which corresponds to the average foraging distance of the main wild pollinator groups including solitary bees, hoverflies and bumble bees (Gathmann and Tscharntke 2002; Wratten et al. 2003; Elliott 2009). The landscape and potential regional pollinator community were similar around the study sites.

\section{Insect sampling and identification}

The abundance and species richness of flower visitors at the faba bean and MHEP were recorded using transect walks. The insect samplings were conducted between February and April 2019 when faba bean and MHEP were flowering. Four insect samplings were carried out; three during the blooming of the main crop (13-14 February, 26-27
February and 11-12 March) and one after (26-27 April). Each sampling lasted 2 days (4 fields per day). We assessed the impact of the FAP approach on faba bean pollinators using data from three insect samplings (i.e. when faba bean was in bloom) (Table 1) and we investigated the impact of the FAP approach on supporting pollinators in the agroecosystem using the pollinators recorded in the four insect samplings (i.e. during and outside the blooming period of the main crop) (Table 1). The sampling of flower visitors in the $75 \%$ zone in FAP and control fields consisted of walking alongside two transect corridors of $28 \mathrm{~m}$ long and $4 \mathrm{~m}$ wide during 5 min each (Fig. 1b). The collector walked slowly in the middle of the $4 \mathrm{~m}$ transect corridor and collected the insects visiting the faba bean flowers on both sides. The flower visitors of MHEP were collected alongside a transect of $80 \mathrm{~m}$ long and $1 \mathrm{~m}$ wide during $10 \mathrm{~min}$ (Fig. 1b), pausing the timer to note the MHEP from which the specimens were collected. In the $25 \%$ zone of the control fields the flower visitors were recorded alongside a transect of $80 \mathrm{~m}$ long and $1 \mathrm{~m}$ wide for $10 \mathrm{~min}$ (Fig. 1b). The insects were collected using a sweep net and an insect vacuum.

All insects that visited the flowers were collected except honey bees (Apis mellifera), the bumblebee (Bombus terrestris) and the carpenter bee (Xylocopa pubescens), that were counted and identified visually on site. The collected insects were put inside killing jars filled with cyanide, then transported back to the lab where they were pinned and labeled. The wild bees were identified to the genus level using the key of Michez et al. (2019) then sent to specialists for identification to the species level using comparative collections or identification keys (Brooks 1988; Priesner 1957; Osten et al. 2000; Michez et al. 2004; Bogusch and Straka 2012). The remaining Hymenoptera and insect visitors were identified by the authors to the lowest taxonomic level feasible.

\section{Statistical analyses}

All analyses were conducted with R statistical software (version 3.6.3; R Core Team 2020). The descriptive part on the list of species visiting faba bean and the MHEP was made
Table 1 Flowering time of the main crop and the marketable habitat enhancement plants

\begin{tabular}{|c|c|c|c|c|c|c|c|c|c|c|c|c|c|c|c|c|}
\hline \multirow{3}{*}{$\begin{array}{l}\text { Months } \\
\text { Weeks } \\
\text { Faba bean (FAP) }\end{array}$} & \multicolumn{4}{|c|}{ Jan-19 } & \multicolumn{4}{|c|}{ Feb-19 } & \multicolumn{4}{|c|}{ Mar-19 } & \multicolumn{4}{|c|}{ Apr-19 } \\
\hline & 1 & 2 & 3 & 4 & 1 & 2 & 3 & 4 & 1 & 2 & 3 & 4 & 1 & 2 & 3 & 4 \\
\hline & & & & & & & & & & & & & & & & \\
\hline Faba bean (Contr & & & & & & & & & & & & & & & & \\
\hline Coriander & & & & & & & & & & & & & & & & \\
\hline Canola & & & & & & & & & & & & & & & & \\
\hline Arugula & & & & & & & & & & & & & & & & \\
\hline Flax & & & & & & & & & & & & & & & & \\
\hline Chia & & & & & & & & & & & & & & & & \\
\hline
\end{tabular}

The grey color represents the flowering time and the black bars the insect sampling time 
including the eight studied fields. For the statistical analysis of the comparison between treatments, we excluded two FAP fields that were not successfully maintained (lack of water and nutrients and injury from plant pests and diseases) to ensure fair comparison between trials, that can be potentially biased by the low maintenance of these fields.

\section{Impact of FAP approach on flower visitor community}

We assessed the impact of the FAP approach on supporting pollinators and promoting pollination service by comparing two pollinator variables: abundance (the number of flower visitors/field/sampling) and species richness (the number of flower visitor species/field/sampling), both in $100 \%$ of the fields and in $75 \%$ of the fields. First, we investigated the effect of the approach on supporting pollinators in the agroecosystem by comparing pollinator variables between FAP and control fields in $100 \%$ of the field area (i.e., the addition of the 3 transects, 2 transects from the $75 \%$ central zone with faba bean and the transect from the $25 \%$ zone with faba bean or MHEP). Second, as pollinator visits to flowers are a reliable predictor of pollination service (Garibaldi et al., 2013), we assessed the contribution of the approach to pollination service by comparing pollinator variables between FAP and control fields in the $75 \%$ central zone with faba bean. We analyzed separately the abundance of honey bees and wild pollinators, as honey bees were by far the most abundant. Linear Mixed Models (LMM) were used to test for differences in pollinator abundance and species richness between FAP and control fields when data were normally distributed. When test assumption of normality was not met and pollinator variables (i.e. pollinator abundance and species richness) could not be transformed to normality, Generalized Linear Mixed Models (GLMM) were used. Generalized linear mixed models were fitted with negative binomial error distribution. We included field as a random effect to account for the multiple samplings per field. The normality was tested numerically using a Shapiro test (Mvnormtest package; Jarek 2012). Linear mixed models and generalized linear mixed models with a negative binomial distribution were fitted with the function lmer and glmer.nb, respectively from the lme4 library (Bates et al. 2015). Generalized linear mixed models were tested for over-dispersion using the dispersion_glmer function in the package blmeco (Korner-Nievergelt et al. 2015) and P values of the linear mixed model residues were interpreted using Satterthwaite's approximations to determine denominator degrees of freedom within the package lmerTest (Alexandra et al. 2020).

\section{Plant-visitor network}

The observed visitors of faba bean and MHEP were pooled within a single visitation matrix $\left(\mathrm{I}^{*} \mathrm{~J}\right)$, in which visitor species are listed in rows, and plant species in columns. The cell values in the matrix indicated the abundance of visitor 'I' on plant species ' $J$ '. The plant visitation network was made using the visitation matrix ( $\left.\mathrm{I}^{*} \mathrm{~J}\right)$. To highlight the most important MHEP that strengthen the network we quantified four species-level indices: degree, species strength, effective partners and proportional generality. The species degree indicates the number of interactions per target species. In this case it is the sum of flower visitor species related to a single plant species. The species strength is the sum of dependencies of each species (i.e., number of links per species, weighted by the number of interactions) (Bascompte et al. 2006), it aims at quantifying a species' abundance across all its partners (Dormann et al. 2020). The number of effective partners equals the number of partners of a species assuming that all the interactions were equally common. Within a plant-visitor network, the proportional generality presents the number of plants visited by a pollinator in relation to the number of plants resources available in the network (Dormann et al. 2009).

We constructed the bipartite quantitative (weighted) network using the package Bipartite (Dormann et al. 2020) and the species-level indices were assessed using the function Species level within the same package.

\section{Pollinators in common between faba bean and MHEP in FAP fields}

We pooled the visitation data of each crop (faba bean and MHEP) from the four insect samplings and the different plots within a weighted matrix, in which the flower visitors are listed in columns and faba bean and the five MHEP are listed in rows. To determine how similar the flower visitor community was between faba bean in FAP fields and each MHEP, we measured the Bray-Curtis (BC) dissimilarity distance among pairs of crops (faba bean in FAP fields vs MHEP) using the package Vegan with the function Vegdist (Oksanen et al. 2019).

\section{Results}

In total, 825 insect flower visitors were collected in this study belonging to 62 species or morphospecies. Based on the checklist of the wild bees of Morocco (Lhomme et al. 2020), almost half of the species are new records for this region (Online Resource 2).

\section{Insect visitors of faba bean}

We recorded 261 visitors on faba bean flowers belonging to 17 species and five families of Hymenoptera (99\%) and two families of Lepidoptera (1\%). $93 \%$ of faba bean visitors 
recorded were Apidae, 3\% were Andrenidae, 2\% belonged to Scoliidae and Tiphiidae and 2\% included Pieridae, Halictidae and Sphingidae (Table 2).

\section{Impact of FAP approach on flower visitor community of MHEP and faba bean}

The comparison between FAP and control fields was performed using the three control fields and the three FAP fields that were properly maintained. The flower visitor abundance on entire fields was four times higher in FAP fields compared to control fields (514 and 116 flower visitors recorded in three FAP and all control fields together, respectively). Considering separately wild pollinators and honey bees in $100 \%$ of the fields, abundance of wild pollinators visiting FAP fields was significantly higher in comparison to control fields (GLMM; $\mathrm{P}=9.3 * 10^{-8}$; Fig. 2a). The abundance of honey bees in $100 \%$ of the fields did not exhibit a significant difference among the treatments (GLMM; $\mathrm{P}=0.66$; Fig. 2b). The wild pollinator abundance in the $75 \%$ zone (i.e. faba bean) did not vary significantly among FAP and control fields (GLMM; $\mathrm{P}=0.06$; Fig. 2c). Honey bee abundance in the $75 \%$ zone was not significantly supported by the FAP approach (GLMM; P=0.382; Fig. 2d).

The wild pollinator species richness was significantly higher in FAP fields than in control fields in $100 \%$ of the fields (GLMM; $\mathrm{P}=4.5^{*} 10^{-7} ; \mathrm{Fig}$. 2e). The difference in wild pollinator species richness recorded in the $75 \%$ zone was not significant among FAP and control (LMM; $\mathrm{P}=0.226$; Fig. 2f).

All the species-level indices (i.e. degree, species strength, effective partners and proportional generality) were higher in faba bean in FAP fields than faba bean in control fields (Table 3). The total number of interactions and the sum of dependencies of faba bean in FAP fields compared to control fields were higher. Although the proportional generality is low in FAP fields, it remains higher compared to faba bean in control fields.

Due to MHEP, the blooming period in FAP fields started two weeks before the blooming of the main crop and extended over 4 weeks after the end of blooming of the main crop (Table 1).

\section{Pollinator shared between faba bean and MHEP in FAP fields}

In total, 564 visitors belonging to 61 species have been recorded during all transect walks on MHEP. Coriander had the highest pollinator density $\left(4.2\right.$ individuals $\left./ \mathrm{m}^{2}\right)$, followed by flax (2.3 individuals $\left./ \mathrm{m}^{2}\right)$ and chia (1.85 individuals $\left./ \mathrm{m}^{2}\right)$. Canola and arugula attracted 1.5 individuals $/ \mathrm{m}^{2}$ and 0.57 individual $/ \mathrm{m}^{2}$, respectively. Similarly, pollinator species density showed a similar trend. Indeed, chia, flax and coriander presented the highest species density with $(0.95$ species/ $\left.\mathrm{m}^{2}\right),\left(0.75\right.$ species $\left./ \mathrm{m}^{2}\right)$ and $\left(0.65\right.$ species $\left./ \mathrm{m}^{2}\right)$, respectively. Followed by canola $\left(0.2\right.$ species $\left./ \mathrm{m}^{2}\right)$ and arugula $(0.14$ species $/ \mathrm{m}^{2}$ ) (Online resources 3, 4, 5, 6 and 7).
Table 2 Rank abundance of faba bean flower visitor species

\begin{tabular}{lllcll}
\hline Species & Family & Rank & Abundance & Proportion & Accumfreq \\
\hline Apis mellifera & Apidae & 1 & 169 & 64.8 & 64.8 \\
Anthophora fulvitarsis & Apidae & 2 & 25 & 9.6 & 74.3 \\
Eucera nigrilabris & Apidae & 3 & 18 & 6.9 & 81.2 \\
Eucera numida & Apidae & 4 & 14 & 5.4 & 86.6 \\
Anthophora sp. & Apidae & 5 & 6 & 2.3 & 88.9 \\
Andrena aerinifrons & Andrenidae & 6 & 5 & 1.9 & 90.8 \\
Eucera sp. & Apidae & 7 & 5 & 1.9 & 92.7 \\
Dasyscolia ciliata & Scoliidae & 8 & 3 & 1.1 & 93.9 \\
Tiphia sp. & Tiphiidae & 9 & 3 & 1.1 & 95 \\
Anthophora dispar & Apidae & 10 & 2 & 0.8 & 95.8 \\
Pieridae sp1 & Pieridae & 11 & 2 & 0.8 & 96.6 \\
Andrena flavipes & Andrenidae & 12 & 1 & 0.4 & 96.9 \\
Andrena sp. & Andrenidae & 13 & 1 & 0.4 & 97.3 \\
Andrena verticalis & Andrenidae & 14 & 1 & 0.4 & 97.7 \\
Bombus terrestris & Apidae & 15 & 1 & 0.4 & 98.1 \\
Eucera clypeata & Apidae & 16 & 1 & 0.4 & 98.5 \\
Lasioglossum sp. & Halictidae & 17 & 1 & 0.4 & 98.9 \\
Melecta spl & Apidae & 18 & 1 & 0.4 & 99.2 \\
Nomada sp14 & Apidae & 19 & 1 & 0.4 & 99.6 \\
Sphingidae sp. & Sphingidae & 20 & 1 & 0.4 & 100 \\
\hline
\end{tabular}



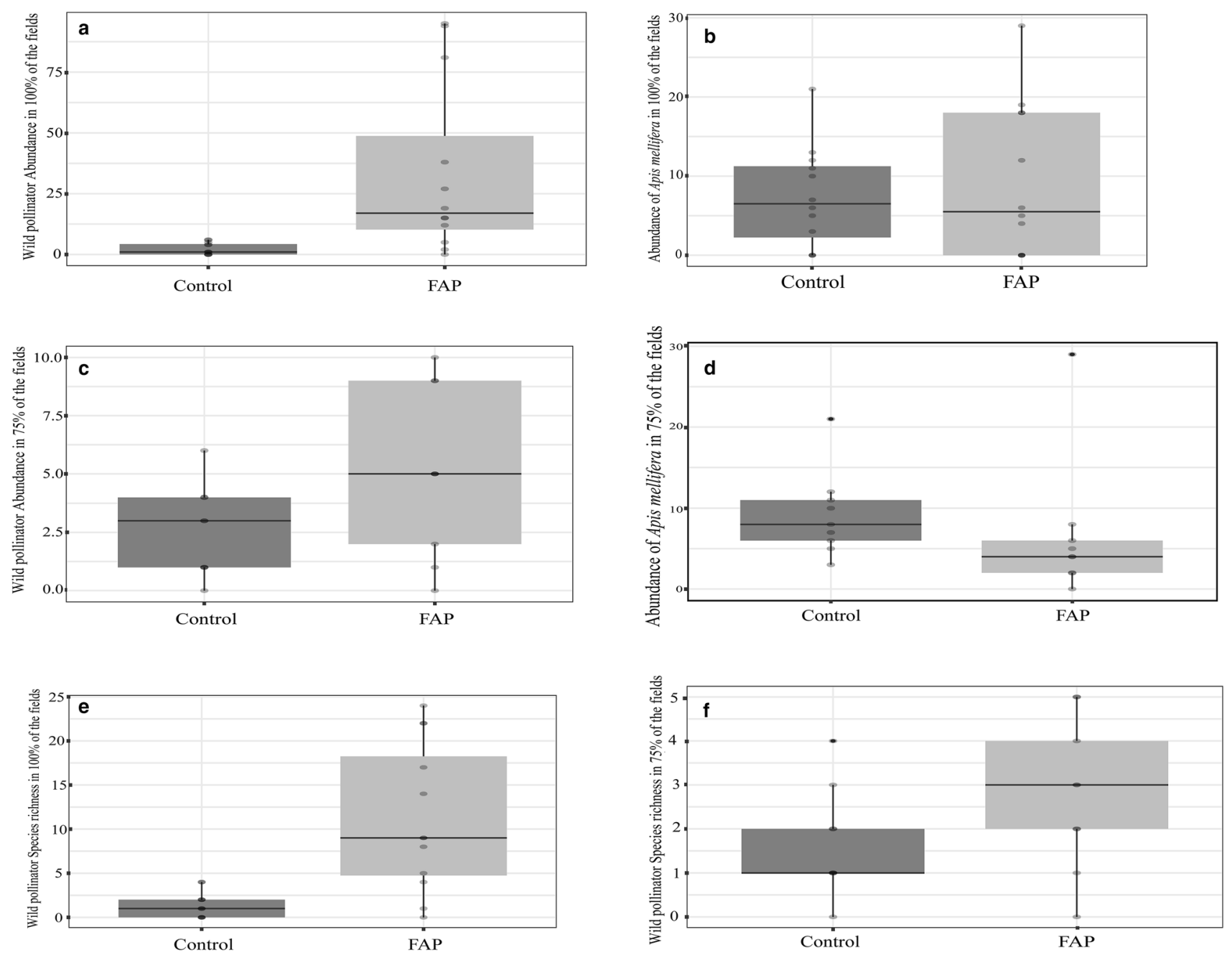

Fig. 2 a Wild pollinator abundance in the whole FAP and control fields, b Honey bee abundance in the whole FAP and control fields, c Wild pollinator abundance in the $75 \%$ zone in FAP and control fields, d Honey bee abundance in the $75 \%$ zone in FAP and control fields, $\mathbf{e}$ Wild pollinator species richness in the whole FAP and control fields, f Wild pollinator species richness in the $75 \%$ zone in FAP and control

fields. Box plots show the median and $25-75 \%$ percentiles. Whiskers show all data excluding outliers. Outliers (circles) are values being more than 1.5 times box length from upper and lower edge of respective box. Asterisks indicate significant differences (Linear mixed model and generalized linear mixed models with negative binomial distribution; $* \mathrm{P}<0.05$; ** $\mathrm{P}<0.01$, *** $\mathrm{P}<0.001$ )

Table 3 Comparison of species-level indices among the low trophic nodes (MHEP and faba bean in FAP and control fields)

\begin{tabular}{lrrll}
\hline & Degree & Species strength & $\begin{array}{l}\text { Effective } \\
\text { partners }\end{array}$ & $\begin{array}{l}\text { Proportional } \\
\text { generality }\end{array}$ \\
\hline Canola & 28 & 15.96 & 13.7 & 0.8 \\
Coriander & 21 & 13.58 & 12.4 & 0.72 \\
Arugula & 20 & 9.04 & 11.1 & 0.64 \\
Flax & 9 & 1.49 & 6.4 & 0.37 \\
Chia & 19 & 10.04 & 17.3 & 1.01 \\
Faba bean FAP & 14 & 6.54 & 5 & 0.29 \\
Faba bean & 9 & 3.32 & 2.5 & 0.14 \\
$\quad$ control & & & & \\
\hline
\end{tabular}

The species-level indices of canola showed the highest effective partners, species degree, species strength and proportional generality in the visitation network, followed by coriander, arugula, chia and flax respectively (Table 3 ). As result, canola was highly dominant in the network with broader visitor's breadth (Fig. 3).

All MHEP overlapped in term of insect visitors with faba bean. The BC distance showed that $30 \%$ of flower visitors occurred in both MHEP and faba bean. Though, the BC distance (Fig. 4) and the composition of species overlap differed among the MHEP. Specifically, the BC distance in the community of pollinators between faba bean and canola, arugula, flax, chia and coriander were $0.64,0.79,0.79,0.87$ and 0.98 respectively. Canola was visited by A. mellifera, Dasyscolia ciliata, Andrena aerinifrons, Eucera nigrilabris 


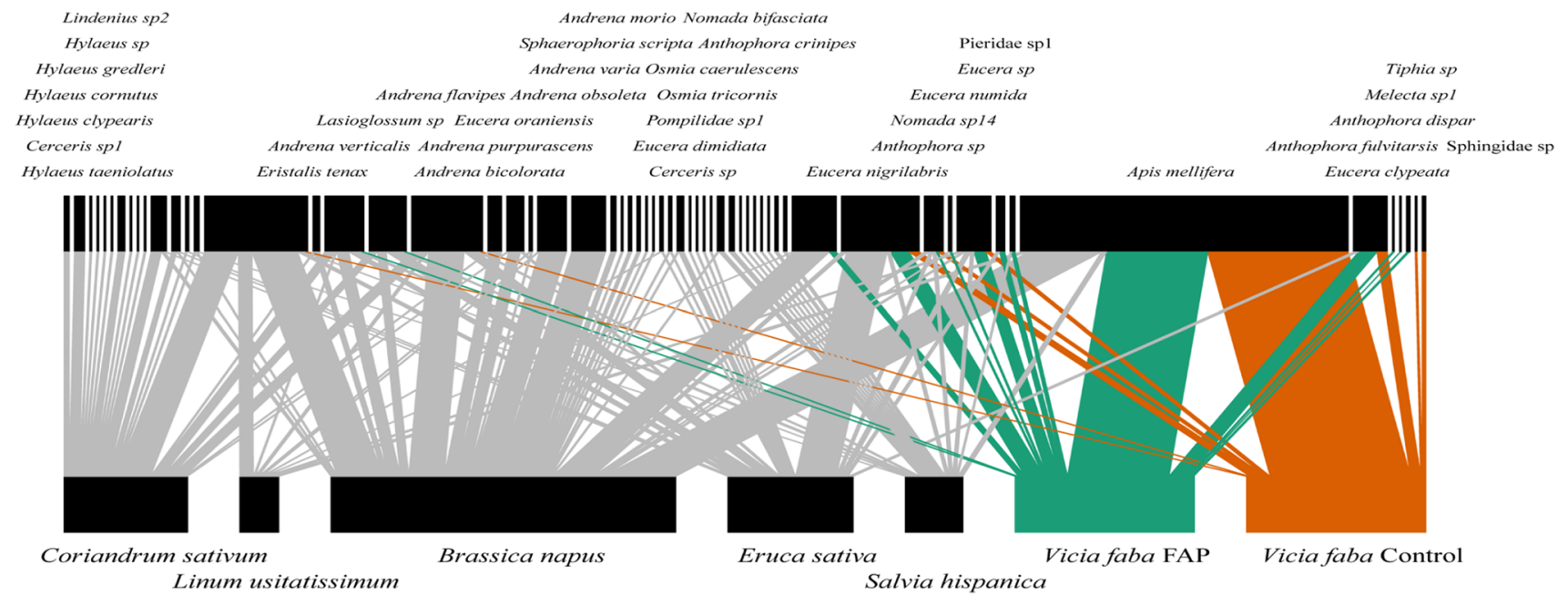

Fig. 3 Plant-visitor network. The lower section represents the plant species (MHEP + faba bean in FAP and control Fields), the upper section indicates the pollinator community. Interactions between species of the two trophic levels are represented in grey, except for faba beans

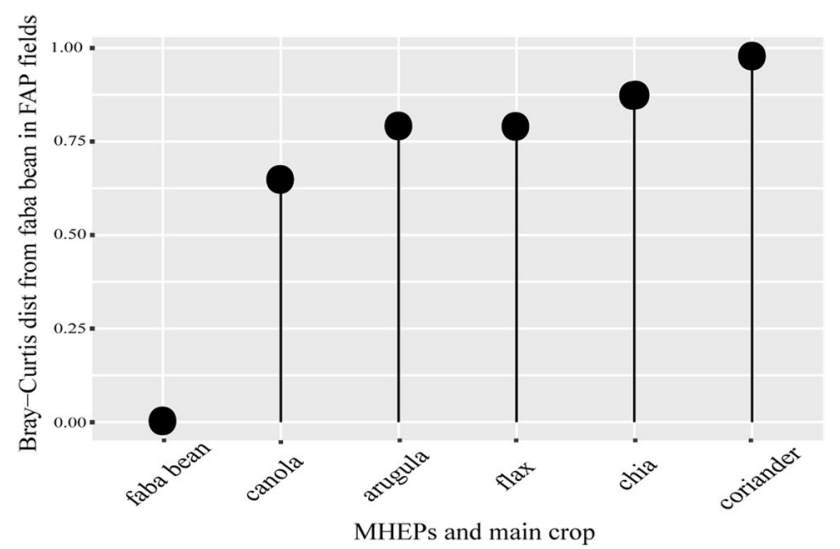

Fig. 4 Results of Bray-Curtis dissimilarity distance of MHEP to faba bean. The black bars represent the distance of MHEP from faba bean

and shared these bee species with the main crop. Faba bean was mainly visited by Anthophora fulvitarsis and $E$. nigrilabris and shared these bee species with arugula. Flax was frequently visited by A. mellifera, D. ciliata and Eucera numida that were also recorded in the main crop, whereas chia shared A. mellifera and E. numida, Anthophora sp. and E. nigrilabris with faba bean.

\section{Discussion}

\section{Faba bean visitors}

Our findings revealed that faba bean was visited in Settat by 17 insect species and that $93 \%$ of the specimens recorded and its interactions in FAP fields, which are represented in green, and faba beans and its interactions in control fields, which are represented in orange. Bars for MHEP and their visitors are grey

on faba bean flowers belonged to Apidae family. The three major groups comprising $99 \%$ of the total visits from this family; were Apis (70\%), Eucera (16\%) and Anthophora $(13 \%)$. These visitors are all generalist long tongued bees (Michez et al. 2019). They are able to reach the curved nectar tube of the corolla while other genera like Andrena, present on other plants in FAP field, have probably a too short tongue. Faba bean visitors can benefit from high content of sugar concentration in the nectar (Stoddard and Bond 1987; Köpke and Nemecek 2010) and great protein content in the pollen (Samorville 2002; Vaudo et al. 2020).

These results confirmed the results of previous studies on faba bean visitors from other countries. The honey bees A. mellifera was recorded as one of the frequent flower visitors of faba bean in many countries (Pierre et al. 1996; Cunningham and Le Feuvre 2013) including Mediterranean countries like Algeria (Aouar-sadli et al. 2008). On the contrary, the genera Anthophora and Eucera are major wild bee groups recorded in faba bean only in Mediterranean countries like Spain and Algeria (Bond and Kirby 1999; Benachour et al. 2007; Aouar-sadli et al. 2008; Shebl and Farag 2015). At species level, to our knowledge, it is the first time that A. fulvitarsis and E. nigrilabris are recorded on faba bean. In northern Europe, visitors of faba bean are mainly bumble bees (Garratt et al. 2014) but in Morocco these species are rare and only one individual of Bombus terrestris was observed during this study. The low abundance of bumble bees recorded in this study could be explained by the climate. In fact, bumble bees are cold-adapted species that are relatively more abundant in cooler climates (Rasmont et al. 2015). Further, the early flowering time of faba bean that occurred during colony growth of bumble 
bees (Rasmont et al. 2008, 2015) may also explain the low abundance of bumble bees. Other solitary bee species from genera Andrena, Lasioglossum, Melecta and Nomada were less frequent (i.e. recorded once or twice foraging on faba bean flowers in our study), these results are similar to those suggested in several studies (Bond and Kirby 1999; Benachour et al. 2007; Shebl and Farag 2015).

Though wild pollinators recorded on faba bean were less abundant than honey bees, previous studies found the pollination efficiency of wild pollinators to be higher compared with honey bees (Kendall and Smith 1975; Marzinzig et al. 2018). Wild pollinators, particularly solitary bees handle flowers more efficiently than honey bees, they make more contact with the reproductive organs and exhibit legitimate flower visits (Marzinzig et al. 2018).

\section{Impact of the FAP approach on flower visitor community}

The visitor species abundance and richness were significantly higher in FAP fields than control fields. This additional diversity is associated to the higher plant diversity in FAP fields and the long bloom duration of the MHEP. The 28 new records for the region were all collected in FAP fields and only two species out of the total 28 bee species were recorded in control fields.

Previous studies highlighted the positive relationship between floral resources richness and pollinator diversity (Ebeling et al. 2012; Isbell et al. 2017; Garibaldi et al. 2019) and provided evidence that flower strips increase pollinator diversity at the field edge but show no consistent spillover into the main crop (Zamorano et al. 2020). Some wild bees such as bumble bees tend to prefer fields with diverse floral resources to meet their food requirements at a reduced foraging cost (Goulson 2003).

Bee species recorded in MHEP were present in the surrounding areas. However, given the landscape composition in the study region where cultivated lands occupy $90 \%$ of the landscape area, some species could be present but not necessarily in high number. Mass flowering MHEP such as coriander, canola and arugula probably created a magnet effect, because the high density of available flowers attracted pollinators from the surrounding areas. This could boost their abundance and help to maintain their populations in the next season. The bee species from the genera: Hylaeus, Sphecodes, Osmia and Xylocopa sampled during this study were recorded only on MHEP as they are mainly generalist and need to diversify their resources (Michez et al. 2019). To meet their optimal nutritional requirement, bees need to balance their intake from various plants (Vaudo et al. 2020). Even if pollinator dependent crops may provide a large quantity of flower rewards, these habitats may fail to support bee health since they provide a single source of pollen or nectar
(Vaudo et al. 2015). The presence of MHEP can be even more critical for specialist species as they can have high pollen requirement of the respective host plant, with up to 1000 flowers needed to rear a single larvae (Müller et al. 2006). Global pollinator decline is strongly associated with expansion of monocultures at the expense of semi natural areas that provide pollinators with diverse and copious floral rewards (Potts et al. 2010; Goulson 2019). Consequently, many studies (Isbell et al. 2017; Sutter et al. 2017; Garibaldi et al. 2019; Bennett et al. 2020) recommended to provide a range of floral resources for different pollinator species to meet their specific diet requirements and thus help to sustain healthy populations that can endure disease and stress (Vaudo et al. 2015).

In line with previous studies on the impact of wildflower hedgerows and strips (Morandin and Kremen 2013; Albrecht et al. 2020), MHEP did not increase crop pollinator abundance and species richness. This finding could be explained by the time of the establishment of MHEP, which was identified as an important driver of variability in effectiveness of flower strips on crop pollinator abundance and species richness (Albrecht et al. 2020). As Morandin and Kremen (2013) confirmed for hedgerows, newly established MHEP may act as a magnet effect, rather than inducing a spillover of pollinators towards the main crop. Since wild bee communities oscillate from year to year and species need time to colonize new habitats, the success of MHEP in enhancing crop pollinator abundance and species richness may increase with their age, as it was confirmed for wild flower strips (Blaauw and Isaacs 2014).

\section{Pollinator species overlap in FAP fields}

A proportion of $30 \%$ of the flower visiting species collected on faba bean were also recorded on the MHEP. The mass flowering crops with high number of flowers such as coriander attract high numbers of insect visitors (Westphal et al. 2003). Coriander is characterized by several pollinatorattractive traits (e.g. exposed nectar, abundant pollen production, high floral coverage and open flowers) allowing a great variety of flower visiting insect species to access its' flower rewards (Bendifallah et al. 2013; Azpiazu et al. 2020). Though, the majority of studies on coriander pollinators did not report visits of long tongue bees (Singh et al. 2010; Bendifallah et al. 2013; Sharma and Meena 2019).

Although chia is a self-pollinating plant, many insect species are attracted to its flowers (Vastola 2015), which is corroborated by our results. Chia did not share a high proportion of flower visiting species with faba bean, probably because chia occupied a small surface in FAP fields $\left(4 \mathrm{~m}^{2}\right)$ or its' different flower shape compared to faba bean excluded bee groups visiting Fabaceae from accessing nectaries due to long corolla tubes, narrow flower entrances 
or lack of landing surfaces (Wester and Claßen-Bockhoff 2007; Wester et al. 2020). The great pollinator abundance and species densities recorded in flax are in conformity with the findings of Navatha et al. (2012) who reported that flax attracts diverse and abundant flower visitors. This diversity could be explained by the high number of the rewarding showy flowers of flax (Thom et al. 2018). The low proportion of insect visitors shared with faba bean and flax could be attributed to the limited area devoted to plant it within FAP fields $\left(4 \mathrm{~m}^{2}\right)$.

The wide-open flowers and the large amounts of nectar and pollen produced by cabbage plants such as canola (Bommarco et al. 2012) and arugula (Masierowska 2003) attract a high number of pollinator species. Though pollinator abundance and species densities on these plants were not high compared to the other MHEP, they are still important given the high number of pollinator species collected on these plants (Online resources 3 and 5). The great proportion of pollinator species, which shared faba bean, canola and arugula as foraging resource could be explained by the large area occupied by these plants ( 30 $\mathrm{m}^{2}$ for each). Even if coriander and chia did not share a great number of flower visitor species with faba bean, they hosted a wide range of insect species belonging to diverse pollinator groups from wild bees (Osmia, Andrena, Hylaeus, Lasioglossum, Xylocopa, Sphecodes) to sphecid wasps (Cerceris, Oxybelus), hover flies (Eristalis, Episyphus) and butterflies (Pieridae).

The high amount of nectar and volatile oils produced by coriander (Kant et al. 2019) also attract a large number of natural enemies (Bendifallah et al. 2013; Kant et al. 2019; Sharma and Meena 2019). Throughout the insect samplings, several predators were observed on the MHEP and in the main crop (ladybirds, hover flies, sphecid wasps and parasitoid wasps). These natural enemies may also contribute to pest control in faba bean and MHEP, consequently preventing losses in yield and farmers income (Christmann et al. 2017).

The FAP approach with the use of diverse MHEP varying in bloom phenology and functional traits supported a diverse range of pollinators throughout the flowering period of faba bean as well as before and after. The approach is highly efficient from a pollinator conservation point of view. From the farmers' perspective, further studies are required to assess the effect of the FAP approach on crop pollination and yield over longer time periods and other crops. The impact of reducing $25 \%$ of the surface of faba bean and increasing the diversity of floral resources in favor of pollinators was visible in pollinator abundance and species richness in the whole fields. Similar to two pilot projects (Christmann et al. 2017, 2021), our experiment showed FAP-induced benefits for pollinator conservation. This approach should be assessed in other countries and different insect pollinated crops, as using MHEP might be more acceptable for farmers than e.g. wildflower strips (Kleijn et al. 2019).

Supplementary Information The online version contains supplementary material available at https://doi.org/10.1007/s10841-021-00351-6.

Acknowledgements We are grateful to Axel Ssymank, Jakub Straka, Andreas Müller, Achik Dorchin, Holger Dathe, Thomas James Wood and Christian Schmid-Egger for the identification of wild pollinators. We would like to thank Youssef Bencharki who participated in this study for his assistance in sowing the fields and Mohamed Chokri for his help with field sampling and data collection. This study is financially supported by The German Federal Ministry for the Environment, Nature Conservation and Nuclear Safety (BMU), within the International Climate Change Initiative (IKI). We would also like to thank the International Center for Agricultural Research in Dry Areas (ICARDA) and the UMONS Research Institute for Biosciences.

\section{Declarations}

Conflict of interest The authors of the manuscript entitled "Farming with Alternative Pollinators" approach increases pollinator abundance and diversity in agro-ecosystems declare that they have no conflict of interest.

Open Access This article is licensed under a Creative Commons Attribution 4.0 International License, which permits use, sharing, adaptation, distribution and reproduction in any medium or format, as long as you give appropriate credit to the original author(s) and the source, provide a link to the Creative Commons licence, and indicate if changes were made. The images or other third party material in this article are included in the article's Creative Commons licence, unless indicated otherwise in a credit line to the material. If material is not included in the article's Creative Commons licence and your intended use is not permitted by statutory regulation or exceeds the permitted use, you will need to obtain permission directly from the copyright holder. To view a copy of this licence, visit http://creativecommons.org/licenses/by/4.0/.

\section{References}

Alexandra K, Brockhoff PB, Christensen RHB, Pødenphant Jensen S (2020) Package lmerTest: tests in linear mixed effects models. R package version, 3.1-3

Aizen MA, Harder LD (2009) The global stock of domesticated honey Bees is growing slower than agricultural demand for pollination. Curr Biol 19:915-918. https://doi.org/10.1016/j.cub.2009.03.071

Aizen MA, Aguiar S, Biesmeijer JC, Garibaldi LA, Inouye DW, Jung C, Martins DJ, Medel R, Morales CL, Ngo H, Pauw A, Paxton RJ, Sáez A, Seymour CL (2019) Global agricultural productivity is threatened by increasing pollinator dependence without a parallel increase in crop diversification. Glob Chang Biol 25:3516-3527. https://doi.org/10.1111/gcb.14736

Albrecht M, Kleijn D, Williams NM, Tschumi M, Blaauw BR, Bommarco R, Campbell AJ, Dainese M, Drummond FA, Entling MH, Ganser D, Arjen de Groot G, Goulson D, Grab H, Hamilton H, Herzog F, Isaacs R, Jacot K, Jeanneret P, Jonsson M, Knop E, Kremen C, Landis DA, Loeb GM, Marini L, McKerchar M, Morandin L, Pfister SC, Potts SG, Rundlöf M, Sardiñas H, Sciligo A, Thies C, Tscharntke T, Venturini E, Veromann E, 
Vollhardt IMG, Wäckers F, Ward K, Wilby A, Woltz M, Wratten S, Sutter L (2020) The effectiveness of flower strips and hedgerows on pest control, pollination services and crop yield: a quantitative synthesis. Ecol Lett 23:1488-1498. https://doi.org/ 10.1111/ele.13576

Aouar-sadli M, Louadi K, Doumandji S (2008) Pollination of the broad bean (Vicia faba L. var. major) (Fabaceae) by wild bees and honey bees (Hymenoptera: Apoidea) and its impact on the seed production in the Tizi-Ouzou area (Algeria). Afr J Agric Res 3:266-272

Azpiazu C, Medina P, Adán Á, Sánchez-Ramos I, del Estal P, Fereres A, Viñuela E (2020) The role of annual flowering plant strips on a melon crop in central Spain. Influence on pollinators and crop. Insects 11(1):66. https://doi.org/10.3390/INSECTS11010066

Bascompte J, Jordano P, Olesen JM (2006) Asymmetric coevolutionary networks facilitate biodiversity maintenance. Science 312(5772):431-433. https://doi.org/10.1126/science.1123412

Bates D, Mächler M, Bolker BM, Walker SC (2015) Fitting linear mixed-effects models using lme4. J Stat Softw. https://doi.org/ 10.18637/jss.v067.i01

Benachour K, Louadi K, Terzo M (2007) Rôle des abeilles sauvages et domestiques (Hymenoptera: Apoidea) dans la pollinisation de la fève (Vicia faba L. var. major) (Fabaceae) en région de Constantine (Algérie). Ann Soc Entomol Fr 43:213-219. https://doi.org/10.1080/00379271.2007.10697513

Bendifallah L, Louadi K, Doumandji S (2013) Bee fauna potential visitors of coriander flowers Coriandrum sativum L. (Apiaceae) in the Mitidja area (Algeria). J Apic Sci 57:59-70. https://doi.org/10.2478/jas-2013-0017

Bennett JM, Steets JA, Burns JH, Burkle LA, Vamosi JC, Wolowski M, Arceo-Gómez G, Burd M, Durka Ellis AG, Freitas L, Li J, Rodger JG, Ştefan V, Xia J, Knight TM, Ashman TL (2020) Land use and pollinator dependency drives global patterns of pollen limitation in the Anthropocene. Nat Commun 11:1-6. https://doi.org/10.1038/s41467-020-17751-y

Bishop J, Nakagawa S Quantifying crop pollinator dependence and its heterogeneity using multi-level meta-analysis. J Appl Ecol

Blaauw BR, Isaacs R (2014) Flower plantings increase wild bee abundance and the pollination services provided to a pollination-dependent crop. J Appl Ecol 15:701-711. https://doi.org/ 10.1111/1365-2664.12257

Biesmeijer JC, Roberts SPM, Reemer M, Ohlemüller R, Edwards M, Peeters T, Schaffers AP, Potts SG, Kleukers R, Thomas CD, Settele J, Kunin WE (2006) Parallel declines in pollinators and insect-pollinated plants in Britain and the Netherlands. Science 313:351-354. https://doi.org/10.1126/science.1127863

Bogusch P, Straka J (2012) Review and identification of the cuckoo bees of central Europe (Hymenoptera: Halictidae: Sphecodes). Zootaxa. https://doi.org/10.11646/ZOOTAXA.3311.1.1

Bommarco R, Marini L, Vaissière BE (2012) Insect pollination enhances seed yield, quality, and market value in oilseed rape. Oecologia 169:1025-1032. https://doi.org/10.1007/ s00442-012-2271-6

Bond DA, Kirby EJM (1999) Anthophora plumipes (Hymenoptera: Anthophoridae) as a pollinator of broad bean (Vicia faba major). J Apic Res 38:199-203. https://doi.org/10.1080/00218 839.1999.11101010

Brooks RW (1988) Systematics and phylogeny of the Anthophorine bees (Hymenoptera Anthophoridae; Anthophorini). The University of Kansas Bulletin 53(9):436-575

Carré G, Roche P, Chifflet R, Morison N, Bommarco R, HarrisonCripps J, Krewenka K, Potts SG, Roberts SPM, Rodet G, Settele J, Steffan-Dewenter I, Szentgyörgyi H, Tscheulin T, Westphal C, Woyciechowski M, Vaissière BE (2009) Landscape context and habitat type as drivers of bee diversity in
European annual crops. Agric Ecosyst Environ 133:40-47. https://doi.org/10.1016/j.agee.2009.05.001

Christmann S (2019a) Do we realize the full impact of pollinator loss on other ecosystem services and the challenges for any restoration in terrestrial areas? Restor Ecol 27:720-725. https://doi. org/10.1111/rec. 12950

Christmann S (2019b) Under which conditions would a wide support be likely for a Multilateral Environmental Agreement for pollinator protection? Environ Sci Policy 91:1-5. https://doi. org/10.1016/j.envsci.2018.10.004

Christmann S, Aw-Hassan AA (2012) Farming with alternative pollinators (FAP) - An overlooked win-win-strategy for climate change adaptation. Agric Ecosyst Environ 161:161-164. https://doi.org/10.1016/j.agee.2012.07.030

Christmann S, Aw-Hassan A, Rajabov T, Khamraev AS, Tsivelikas A (2017) Farming with alternative pollinators increases yields and incomes of cucumber and sour cherry. Agron Sustain Dev 37(4):24. https://doi.org/10.1007/s13593-017-0433-y

Christmann S, Aw-hassan A, Güler Y, Cumhur H, Bernard M, Smaili MC, Tsivelikas A (2021) Two enabling factors for farmerdriven pollinator protection in low- and middle-income countries. Int J Agric Sustain. https://doi.org/10.1080/14735903. 2021.1916254

Cunningham SA, Le Feuvre D (2013) Significant yield benefits from honeybee pollination of faba bean (Vicia faba) assessed at field scale. F Crop Res 149:269-275. https://doi.org/10.1016/j.fcr. 2013.05.019

Dormann CF, Frund J, Blüthgen N, Gruber B (2009) Indices, graphs and null models: analyzing bipartite ecological networks. Open Ecol J 2:7-24. https://doi.org/10.2174/1874213000902010007

Dormann CF, Fruend J, Gruber B, Beckett S, Devoto M, Felix G, Iriondo J, Opsahl T, Pinheiro R, Strauss R, Vazquez D, Bluthgen N, Clauset A, Rodriguez-Girones M (2020) Package "bipartite": visualizing bipartite networks and calculating some (ecological) indices $1-175$.

Ebeling A, Klein AM, Weisse WW, Tscharntke T (2012) Multitrophic effects of experimental changes in plant diversity on cavity-nesting bees, wasps, and their parasitoids. Oecologia 169:453-465. https://doi.org/10.1007/s00442-011-2205-8

Eeraerts M, Vanderhaegen R, Smagghe G, Meeus I (2020) Pollination efficiency and foraging behaviour of honey bees and non-Apis bees to sweet cherry. Agric for Entomol 22:75-82. https://doi. org/10.1111/afe. 12363

Elliott SE (2009) Subalpine bumble bee foraging distances and densities in relation to flower availability. Environ Entomol 38:748756. https://doi.org/10.1603/022.038.0327

European Court of Auditors (2020) Special Report: Protection of wild pollinators in the EU- Commission initiatives have not borne fruit. https://www.eca.europa.eu/en/Pages/DocItem.aspx?did= 54200

Ferrier PM, Rucker RR, Thurman WN, Burgett, M (2018) Economic effects and responses to changes in honey bee health 1-48. U.S. Department of Agriculture, Economic Research Service, 246:1-48

Foley JA, DeFries R, Asner GP, Barford C, Bonan G, Carpenter SR, Chapin FS, Coe MT, Daily GC, Gibbs HK, Helkowski JH, Holloway T, Howard EA, Kucharik CJ, Monfreda C, Patz JA, Prentice IC, Ramankutty N, Snyder PK (2005) Global consequences of land use. Science 309:570-574. https://doi.org/10.1126/science. 1111772

Fox J, Weisberg S (2019) An R companion to applied regression, 3rd edn. Sage, Thousand Oaks

Garibaldi LA, Steffan-Dewenter I, Winfree R, Aizen MA, Bommarco R, Cunningham SA, Kremen C, Carvalheiro LG, Harder LD, Afik O, Bartomeus I, Benjamin F, Boreux V, Cariveau D, Chacoff NP, Dudenhöffer JH, Freitas BM, Ghazoul J, Greenleaf 
S, Hipólito J, Holzschuh A, Howlett B, Isaacs R, Javorek SK, Kennedy CM, Krewenka KM, Krishnan S, Mandelik Y, Mayfield MM, Motzke I, Munyuli T, Nault BA, Otieno M, Petersen J, Pisanty G, Potts SG, Rader R, Ricketts TH, Rundlöf M, Seymour CL, Schüepp C, Szentgyörgyi H, Taki H, Tscharntke T, Vergara CH, Viana BF, Wanger TC, Westphal C, Williams N, Klein AM (2013) Wild pollinators enhance fruit set of crops regardless of honey bee abundance. Science 339:1608-1611

Garibaldi LA, Pérez-Méndez N, Garratt MPD, Gemmill-Herren B, Miguez FE, Dicks LV (2019) Policies for ecological intensification of crop production. Trends Ecol Evol 34:282-286. https:// doi.org/10.1016/j.tree.2019.01.003

Garratt MPD, Coston DJ, Truslove CL, Lappage MG, Polce C, Dean R, Biesmeijer JC, Potts SG (2014) The identity of crop pollinators helps target conservation for improved ecosystem services. Biol Conserv 169:128-135. https://doi.org/10.1016/j.biocon. 2013.11.001

Gathmann A, Tscharntke T (2002) Foraging ranges of solitary bees. J Anim Ecol 71:757-764. https://doi.org/10.1046/j.1365-2656. 2002.00641.x

Gill RJ, Baldock KCR, Brown MJF, Cresswell JE, Dicks LV, Fountain MT, Garratt MPD, Gough LA, Heard MS, Holland JM, Ollerton J, Stone GN, Tang CQ, Vanbergen AJ, Vogler AP, Woodward G, Arce AN, Boatman ND, Brand-Hardy R, Breeze TD, Green M, Hartfield CM, O'Connor RS, Osborne JL, Phillips J, Sutton PB, Potts SG (2016) Protecting an ecosystem service: approaches to understanding and mitigating threats to wild insect pollinators. Adv Ecol Res 54:135-206. https://doi.org/10.1016/bs.aecr.2015. 10.007

Goulson D (2003) Bumblebees-their behavior and ecology. Oxford University Press, Oxford

Goulson D (2019) The insect apocalypse and why it matters. Curr Biol 29:967-971. https://doi.org/10.1016/j.cub.2019.06.069

Goulson D, Nicholls E, Botías C, Rotheray EL (2015) Bee declines driven by combined stress from parasites, pesticides, and lack of flowers. Science 347(6229):1255957. https://doi.org/10.1126/ science. 1255957

Granot I, Belmaker J (2020) Niche breadth and species richness: correlation strength, scale and mechanisms. Glob Ecol Biogeogr 29:159-170. https://doi.org/10.1111/geb.13011

Holzschuh A, Dainese M, Gonzalez-Varo J, Mudri-Stojnic S, Riedinger V, Rundlof M, Scheper J, Wickens J, Wickens V, Bommarco R, Kleijn D, Potts SG, Roberts S, Smith H, Vilà M, Vujic A, Steffan-Dewenter I (2016) Mass-flowering crops dilute pollinator abundance in agricultural landscapes across Europe. Ecol Lett 19:1228-1236. https://doi.org/10.1111/ele.12657

IPBES (2016) In: Potts SG, Imperatriz-Fonseca VL, Ngo HT (eds) Individual chapters and their executive summaries of the thematic assessment on pollinators, pollination and food production (deliverable 3(a)). IPBES, Bonn, Germany. http://www.ipbes.net/ sites/default/files/downloads/pdf/

Isbell F, Adler PR, Eisenhauer N, Fornara D, Kimmel K, Kremen C, Letourneau DK, Liebman M, Quijas PHW (2017) Benefits of increasing plant diversity in sustainable agroecosystems. J Ecol 105:871-879. https://doi.org/10.1111/1365-2745.12789

Jarek S (2012) mvnormtest: normality test for multivariate variables. R package version 0.1--9. R Found. Stat. Comput. https://CRAN.Rproject.org $/$ package $=$ mvnormtest pp $1-3$

Kant K, Meena SR, Sharma YK, Meena NK, Vishal MK, Saxena SN, Mishra BK (2019) Development of aphids Hyadaphis coriandri (Das), its natural enemies and pollinators on coriander (Coriandrum sativum L.). Int J Seed Spices 9:79-84

Kendall ADA, Smith BD (1975) The pollinating efficiency of honeybee and bumblebee visits to field bean Flowers (Vicia faba L.). J Appl Ecol 12:709-717. https://doi.org/10.2307/2402083
Kleijn D, Winfree R, Bartomeus I, Carvalheiro LG, Henry M, Isaacs R, Klein AM, Kremen C, M'Gonigl LK, Rader R, Ricketts TH, Williams NM, Lee Adamson N, Ascher JS, Báldi A, Batáry P, Benjamin F, Biesmeijer JC, Blitzer EJ, Bommarco R, Brand MR, Bretagnolle V, Button L, Cariveau DP, Chifflet R, Colville JF, Danforth BN, Elle E, Garratt MPD, Herzog F, Holzschuh A, Howlett BG, Jauker F, Jha S, Knop E, Krewenka KM, Le Féon V, Mandelik Y, May EA, Park MG, Pisanty G, Reemer M, Riedinger V, Rollin O, Rundlöf M, Sardiñas HS, Scheper J, Sciligo AR, Smith HG, Steffan-Dewenter I, Thorp R, Tscharntke T, Verhulst J, Viana BF, Vaissière BE, Veldtman R, Westphal C, Potts SG (2015) Delivery of crop pollination services is an insufficient argument for wild pollinator conservation. Nat Commun 6:71414. https://doi.org/10.1038/ncomms8414

Kleijn D, Bommarco R, Fijen TPM, Garibaldi LA, Potts SG, van der Putten WH (2019) Ecological intensification: bridging the gap between science and practice. Trends Ecol Evol 34:154-166. https://doi.org/10.1016/j.tree.2018.11.002

Klein AM, Steffan-Dewenter I, Tscharntke T (2003) Fruit set of highland coffee increases with the diversity of pollinating bees. Proc R Soc B Biol Sci 270:955-961. https://doi.org/10.1098/rspb. 2002.2306

Klein AM, Vaissière BE, Cane JH, Steffan-Dewenter I, Cunningham SA, Kremen C, Tscharntke T (2007) Importance of pollinators in changing landscapes for world crops. Proc R Soc B Biol Sci 274:303-313. https://doi.org/10.1098/rspb.2006.3721

Köpke U, Nemecek T (2010) Ecological services of faba bean. Food Crop Res 115:217-233. https://doi.org/10.1016/j.fcr.2009.10.012

Korner-Nievergelt F, Roth T, von Felten S, Guelat J, Almasi B, KornerNievergelt $P$ (2015) Bayesian data analysis in ecology using linear models with R, BUGS and Stan. Elsevier, Amsterdam

Kuznetsova A, Brockhoff PB, Christensen RHB (2017) lmerTest package: tests in linear mixed effects models. J Stat Softw 82(13):126. https://doi.org/10.18637/jss.v082.i13

Lever JJ, van Nes EH, Scheffer M, Bascompte J (2014) The sudden collapse of pollinator communities. Ecol Lett 17:350-359. https:// doi.org/10.1111/ele.12236

Lhomme P, Michez D, Christmann S, Scheuchl E, El Abdouni I, Hamroud L, Ihsane O, Sentil A, Smaili MC, Schwarz M, Dathe HH, Strata J, Pauly A, Schmid-Egger C, Patiny S, Terzo M, Müller A, Praz C, Risch S, Kasparek M, Kuhlmann M, Wood TJ, Bogusch P, Ascher JS, Rasmont P (2020) The wild bees (Hymenoptera: Apoidea) of Morocco. Zootaxa

MacInnis G, Forrest JRK (2019) Pollination by wild bees yields larger strawberries than pollination by honey bees. J Appl Ecol 56:824832. https://doi.org/10.1111/1365-2664.13344

Martins KT, Gonzalez A, Lechowicz MJ (2015) Pollination services are mediated by bee functional diversity and landscape context. Agric Ecosyst Environ 200:12-20. https://doi.org/10.1016/j.agee. 2014.10.018

Marzinzig B, Brünjes L, Biagioni S, Behling H, Link W, Westphal C (2018) Bee pollinators of faba bean (Vicia faba L.) differ in their foraging behaviour and pollination efficiency. Agric Ecosyst Environ 264:24-33. https://doi.org/10.1016/j.agee.2018.05.003

Masierowska ML (2003) Floral nectaries and nectar production in brown mustard (Brassica juncea) and white mustard (Sinapis alba) (Brassicaceae). Plant Syst Evol 238:97-107. https://doi. org/10.1007/s00606-002-0273-2

Matieres DES (2019) Rapport de synthèse sur l'agriculture au Maroc.

Mccracken ME, Woodcock BA, Lobley M, Pywell RF, Saratsi E, Swetnam RD, Mortimer SR, Harris SJ, Winter M, Hinsley S, Bullock JM (2015) Social and ecological drivers of success in agri-environment schemes: the roles of farmers and environmental context. J Appl Ecol 52:696-705. https://doi.org/10.1111/ 1365-2664.12412 
Michez D, Terzo M, Rasmont P (2004) Révision des espèces ouestpaléarctiques du genre Dasypoda Latreille 1802 (Hymenoptera, Apoidea, Melittidae). Linzer Biologische Beiträge 36(2):847-900

Michez D, Rasmont P, Terzo M, Vereecken NJ, 2019. Bees of Europe, first ed. NAP Editions, $548 \mathrm{pp}$.

Ministry of Agriculture, Fisheries, Rural development, Water and Forests (2019) Prévisions d'une bonne campagne agricole, moyenne pour les céréales. http://www.agriculture.gov.ma/pages/actua lites/2018-2019-previsions-d\%E2\%80\%99une-bonne-campa gne-agricole-moyenne-pour-les-cereales

Mogren CL, Rand TA, Fausti SW, Lundgren JG (2016) The Effects of Crop Intensification on the diversity of native pollinator communities. Environ Entomol 45:865-872. https://doi.org/10.1093/ ee/nvw066

Morandin LA, Kremen C (2013) Hedgerow restoration promotes pollinator populations and exports native bees to adjacent fields. Ecol Appl 23:829-839. https://doi.org/10.1890/12-1051.1

Müller A, Diener S, Schnyder S, Stutz K, Sedivy C, Dorn S (2006) Quantitative pollen requirements of solitary bees: implications for bee conservation and the evolution of bee-flower relationships. Biol Conserv 130:604-615. https://doi.org/10.1016/j. biocon.2006.01.023

Navatha L, Sreedevi K, Chaitanya T, Prasad PR, Naidu MVS (2012) Species richness and foraging activity of insect visitors in linseed (Linum usitatissimum L.). Curr Biot 5:465-471

Oksanen J, Blanchet FG, Friendly M, Kindt R, Legendre P, Mcglinn D, Minchin PR, O'hara RB, Simpson GL, Solymos P, Henry M, Stevens H, Szoecs E, Maintainer HW (2019) Package "vegan" title community ecology package. Commun Ecol Packag. 2:1-297

Ollerton J, Winfree R, Tarrant S (2011) How many flowering plants are pollinated by animals? Oikos 120:321-326. https://doi.org/ 10.1111/j.1600-0706.2010.18644.x

Osten T (2000) Die Scoliiden des Mittelmeer-Gebietes und angrenzender Regionen (Hymenoptera). Ein Bestimmungsschlüssel Linzer Biologische Beiträge 32(2):537-593

Palmer RG, Perez PT, Ortiz-Perez E, Maalouf F, Suso MJ (2009) The role of crop-pollinator relationships in breeding for pollinator-friendly legumes: from a breeding perspective. Euphytica 170:35-52. https://doi.org/10.1007/s10681-009-9953-0

Pierre J, Le Guen J, Pham Delègue MH, Mesquida J, Marilleau R, Morin G (1996) Comparative study of nectar secretion and attractivity to bees of two lines of spring-type faba bean (Vicia faba L var equina Steudel). Apidologie 27:65-75. https://doi.org/ 10.1051/apido:19960201

Pierre J, Suso MJ, Moreno MT, Esnault R, Le Guen J (1999) Diversité et efficacité de l'entomofaune pollinisatrice (Hymenoptera: Apidae) de la féverole (Vicia faba L.) sur deux sites, en France et en Espagne. Ann La Soc Entomol Fr 35:312-318

Potts SG, Vulliamy B, Roberts S, O'Toole C, Dafni A, Neeman G, Willmer PG (2004) Nectar resource diversity organises flowervisitor community structure. Entomol Exp Appl 113:103-107. https://doi.org/10.1111/j.0013-8703.2004.00212.x

Potts SG, Biesmeijer JC, Kremen C, Neumann P, Schweiger O, Kunin WE (2010) Global pollinator declines: trends, impacts and drivers. Trends Ecol Evol 25:345-353. https://doi.org/10.1016/j.tree. 2010.01.007

Potts SG, Imperatriz-Fonseca V, Ngo HT, Aizen MA, Biesmeijer JC, Breeze TD, Dicks LV, Garibaldi LA, Hill R, Settele J, Vanbergen AJ (2016) Safeguarding pollinators and their values to human well-being. Nature 540:220-229. https://doi.org/10.1038/natur e20588

Priesner H (1957) A review of the Anthophora-species of Egypt (Hymenoptera: Apidae). Bull Soc Entomol 41:1-115
R Development Core Team (2020) R: A language and environment for statistical computing. R Foundation for Statistical Computing, Vienna, Austria

Rasmont P, Coppée A, Michez D, Meulemeester T (2008) An overview of the Bombus terrestris (L. 1758) subspecies (Hymenoptera: Apidae). Ann Soc Entomol Fr 44:243-250

Rasmont P, Franzén M, Lecocq T, Harpke A, Roberts SPM, Biesmeijer JC, Castro L (2015) Climatic risk and distribution atlas of European bumblebees. Pensoft Publishers, Sofia

Reilly JR, Artz DR, Biddinger D, Bobiwash K, Boyle NK, Brittain C, Brokaw J, Campbell JW, Daniels J, Elle E, Ellis JD, Fleischer SJ, Gibbs J, Gillespie RL, Gundersen KB, Gut L, Hoffman G, Joshi N, Lundin O, Mason K, McGrady CM, Peterson SS, PittsSinger TL, Rao S, Rothwell N, Rowe L, Ward KL, Williams NM, Wilson JK, Isaacs R, Winfree R (2020) Crop production in the USA is frequently limited by a lack of pollinators: Pollination limitation in US crops. Proc R Soc B Biol Sci 287:2-9. https:// doi.org/10.1098/rspb.2020.0922rspb20200922

Sánchez-Bayo F, Wyckhuys KAG (2019) Worldwide decline of the entomofauna: a review of its drivers. Biol Conserv 232:8-27. https://doi.org/10.1016/j.biocon.2019.01.020

Service provincial de mise en oeuvre du conseil agricole (SPMOCA) (2019)

Shakeel M, Ali Hussain Ahmad S, Said F, Khan KA, Bashir MA, Anjum SI, Islam W, Ghramh HA, Ansari MJ, Habib A (2019) Insect pollinators diversity and abundance in Eruca sativa Mill. (Arugula) and Brassica rapa L. (Field mustard) crops. Saudi J Biol Sci 26:1704-1709. https://doi.org/10.1016/j.sjbs.2018.08. 012

Sharma K, Meena NK (2019) Diversity of insect pollinators in coriander (Coriandrum sativum Linn.) var. ACR-1 under semi-arid region of Rajasthan. J Pharmacogn Phytochem 8:198-201

Shebl MA, Farag M (2015) Bee diversity (Hymenoptera: Apoidea) visiting Broad Bean (Vicia faba L.) flowers in Egypt. Zool Middle East 61:256-263. https://doi.org/10.1080/09397140.2015. 1069245

Singh H, Swaminathan R, Hussain T (2010) Influence of certain plant products on the insect pollinators of coriander. J Biopestic 3:208-211

Somerville D (2002) Honeybees in broad bean pollination. Agnote DAI-128, New South Wales Department of Agriculture. No. Reg, 166/26

Steffan-Dewenter I, Münzenberg U, Bürger C, Thies C, Tscharntke T (2002) Scale-dependent effects of landscape context on three pollinator guilds. Ecology 83:1421-1432. https://doi.org/10.1890/ 0012-9658(2002)083[1421:SDEOLC]2.0.CO;2

Stoddard FL, Bond DA (1987) The pollination requirements of the faba bean. Bee World 68:144-152. https://doi.org/10.1080/0005772X. 1987.11098923

Sutter L, Jeanneret P, Bartual AM, Bocci G, Albrecht M (2017) Enhancing plant diversity in agricultural landscapes promotes both rare bees and dominant crop-pollinating bees through complementary increase in key floral resources. J Appl Ecol 54:1856-1864. https://doi.org/10.1111/1365-2664.12907

Thom MD, Eberle CA, Forcella F, Gesch R, Weyers S (2018) Specialty oilseed crops provide an abundant source of pollen for pollinators and beneficial insects. J Appl Entomol 142:211-222. https://doi. org/10.1111/jen.12401

Vanbergen AJ, Espíndola A, Aizen MA (2018) Risks to pollinators and pollination from invasive alien species. Nat Ecol Evol. https:// doi.org/10.1038/s41559-017-0412-3

Vastola A (2015) The sustainability of agro-food and natural resource systems in the Mediterranean Basin. Springer International Publising, Cham, pp 1-1397 
Vaudo AD, Tooker JF, Grozinger CM, Patch HM (2015) Bee nutrition and floral resource restoration. Curr Opin Insect Sci 10:133-141. https://doi.org/10.1016/j.cois.2015.05.008

Vaudo AD, Tooker JF, Patch HM, Biddinger DJ, Coccia M, Crone MK, Fiely M, Francis JS, Hines HM, Hodges M, Jackson SW, Michez D, Mu J, RussoL SM, Treanore ED, Vanderplanck M, Yip E, Leonard AS, Grozinger CM (2020) Pollen protein: lipid macronutrient ratios may guide broad patterns of bee species floral preferences. Insects 11:132. https://doi.org/10.3390/insec ts 11020132

Wester P, Claßen-Bockhoff R (2007) Floral diversity and pollen transfer mechanisms in bird-pollinated Salvia species. Ann Bot 100:401-421. https://doi.org/10.1093/aob/mcm036

Wester P, Lunau K (2017) Plant-pollinator communication, advances in botanical research. Elsevier Ltd. https://doi.org/10.1016/bs. abr.2016.10.004

Wester P, Cairampoma L, Haag S, Schramme J, Neumeyer C, ClaßenBockhoff R (2020) Bee exclusion in bird-pollinated Salvia flowers - the role of flower colour versus flower construction. Int $\mathbf{J}$ Plant Sci. https://doi.org/10.1086/709132

Westphal C, Steffan-Dewenter I, Tscharntke T (2003) Mass flowering crops enhance pollinator densities at a landscape scale. Ecol Lett 6:961-965. https://doi.org/10.1046/j.1461-0248.2003.00523.x
Williams NM, Minckley RL, Silveira FA (2001) Variation in native bee faunas and its implications for detecting community changes. Conserv Ecol 5(1):7

Wratten SD, Bowie MH, Hickman JM, Evans AM, Sedcole JR, Tylianakis JM (2003) Field boundaries as barriers to movement of hover flies (Diptera: Syrphidae) in cultivated land. Oecologia 134:605-611. https://doi.org/10.1007/s00442-002-1128-9

Zamorano J, Bartomeus I, Grez AA, Garibaldi LA (2020) Field margin floral enhancements increase pollinator diversity at the field edge but show no consistent spillover into the crop field: a meta-analysis. Insect Conserv Divers. https://doi.org/10.1111/icad.12454

Zhang H, Huang J, Williams PH, Vaissière BE, Zhou Z, Gai Q, Dong J, An J (2015) Managed bumblebees outperform honeybees in increasing peach fruit set in China: different limiting processes with different pollinators. PLoS ONE 10(3):e0121143. https:// doi.org/10.1371/journal.pone.0121143

Publisher's Note Springer Nature remains neutral with regard to jurisdictional claims in published maps and institutional affiliations. 